\title{
Epistemically reinforced kyl(lä)/küll-responses in Estonian and Finnish: Word order and social action
}

Leelo Keevallik and Auli Hakulinen

The self-archived postprint version of this journal article is available at Linköping University Institutional Repository (DiVA):

http:/ / urn.kb.se/ resolve?urn=urn:nbn:se:liu:diva- 140152

N.B.: When citing this work, cite the original publication.

Keevallik, L., Hakulinen, A., (2017), Epistemically reinforced kyl(lä)/ küll-responses in Estonian and Finnish: Word order and social action, J ournal of Pragmatics,

https:// doi.org/ 10.1016/j.pragma.2017.01.003

Original publication available at:

https:// doi.org/ 10.1016/j.pragma.2017.01.003

Copyright: Elsevier

http:// www.elsevier.com/

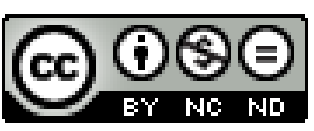




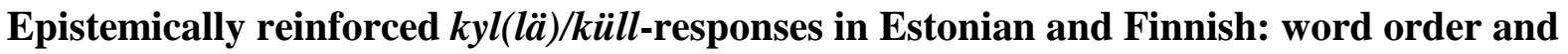 social action \\ Leelo Keevallik ${ }^{1}$, Auli Hakulinen
}

\begin{abstract}
:
This paper looks at responsive actions built with different word orders, targeting the element kyl(lä) in Finnish and küll in Estonian, two close relatives. Depending on the action sequence and syntax, kyl(lä)/küll expresses intensity or speaker certainty, thus epistemically "reinforcing” the proposition. Historically the same lexical item, even though a noun, meaning roughly 'abundance, plentiness' (German 'Menge', 'Reichtum'), kyl(lä)/küll currently occurs in conventionalized patterns which reveal the interface of word order and social action. In both

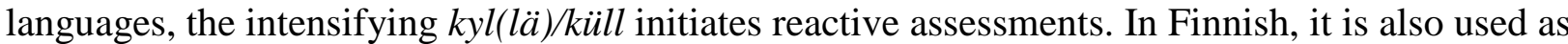
an epistemic adverb that marks speaker certainty, building affirming answers in both unit-initial and unit final positions. In Estonian, the epistemic küll initially formats consoling responses, while in unit-final positions, it is a regular part of a formulaic (dis)affirmation and functions almost like a clitic. The paper argues that word order regarding what have traditionally been seen as syntactically peripheral elements, such as adverbs and particles, can be constitutive of units implementing social actions. It suggests that the sequential analysis of action is a perfect method for revealing subtle semantic and pragmatic differences between the uses of historically close items in related languages.
\end{abstract}

Keywords: interactional linguistics, responsive action, word order, adverb/particle, Finnish, Estonian

\section{Introduction}

In this paper, we trace the use of a single element $\mathrm{kyl}(\mathrm{lä}) / \mathrm{küll}$ contrastively in responsive actions in two closely related languages, Finnish and Estonian. By using the interactional linguistic method, we will show how dimensions of relative knowledge and actions such as affirming, assessing, and consoling find a regular grammatical shape in each of the two languages, as reflected in word order patterns. We thereby aim to demonstrate how sequence-based routinization of action is relevant for understanding the meaning of elusive adverbs or particles, and accordingly argue for the relevance of sequential analysis for the comparative study of linguistic relatives.

Finnish and Estonian belong to the Balto-Finnic group of the Finno-Ugrian language family and have a common proto-language, dating back ca. 2500-3000 years. They share much of the vocabulary and the basic morpho-syntax, with Estonian developing towards a fusional type and Finnish representing a more agglutinative type. (For additional information, see e.g., Grünthal, 2000.) Due to a number of phonological and lexico-syntactic changes during the millennia, the speakers do not easily understand each other across the language border today and mastering subtle pragmatic patterns involving similar words, such as $k y l(l a ̈) / k u ̈ l l$, constitutes a true challenge for language learners on both sides. By targeting a historically "same” item in Finnish and Estonian we contribute to the conceptualization of grammatical structures as constitutive of

\footnotetext{
${ }^{1}$ Leelo Keevallik is grateful to the Center of Excellence in Intersubjectivity in Interaction, Helsinki University, for a generous fellowship that made this collaboration possible.
} 
sequentially organized actions from a comparative perspective. Our broader aim is to show how the word order related to a 'peripheral' syntactic element, an adverb or a particle, implements different social actions.

Responsive turns have attracted massive interest within the research tradition of conversation analysis (starting with Clayman and Heritage, 2002; Raymond, 2003) and interactional linguistics (Couper-Kuhlen and Selting, 2001; Thompson et al., 2015). In an ongoing talk-in-interaction speakers typically build on what has already been said and/or what is commonly known. At specific moments, a participant may be accountable for providing an explicit response, for example an answer when a question has been asked. At other moments, the contribution is more generally reactive to the prior, such as when the speaker is to evaluate what she has just heard. In the present paper we consider grammatical patterns across different kinds of reactiveness, from answers to questions to more generally reactive assessments. A variety of social dimensions, such as degrees of shared knowledge between the participants, accountability, and entitlement, have been shown to play a decisive role in the formatting of responsive actions. Responses to questions and assessments can be designed to achieve specific interactional aims, such as conveying that the speaker has independent epistemic access to the subject matter, or indicating her different perspective (Stivers, 2005; Hakulinen and Sorjonen, 2009; Sorjonen and Hakulinen, 2009; Heritage and Raymond, 2012). The choice between a phrasal or a full sentence response to a wh-question in English reveals whether the terms of the question are accepted to the recipient or not (Fox and Thompson, 2010). On the other hand, by choosing between a particle and a verb repeat answer in Estonian, speakers can display their understanding of the status of the question within an ongoing action sequence (Keevallik, 2010a). There are thus a range of basic grammatical choices in different languages available for indexing social and interactional concerns, and guiding how a response is to be heard.

Likewise, the ordering of elements within turns has been subject to interactional analysis. Several studies have targeted the order between particles and clausal units in responsive turns (e.g. Raymond, 2003), others have shown how utterances in spoken language are produced incrementally, on-line (Tanaka, 2000; Auer, 2009; Iwasaki, 2011). Word order in clauses, however, has mostly been investigated from a more pragmatic angle, showing its relevance in larger discourse units (e.g. Auer and Maschler, 2013; Wide, 2014; Maschler, 2015). A remarkable exception is a series of studies on Finnish responses that have demonstrated a close relationship between social action and the ordering of pronominal and verbal elements (e.g., Hakulinen and Sorjonen, 2009; 2011; Sorjonen and Hakulinen, 2009). Similarly, Swedish word order has been shown to be motivated by interactional and sequential concerns (Lindström, J., 2014). The present study will build on this line of research, focusing on word order that involves a distinct epistemic element $\mathrm{kyl}(\mathrm{lä}) / \mathrm{küll}$. We argue that a) the contribution of $k y l(l a ̈) / k u ̈ l l$ depends

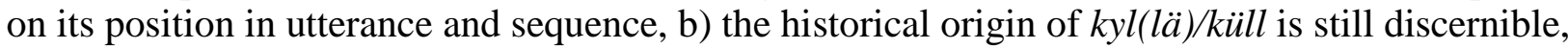
to varying degrees, in its current usages, c) differently ordered elements can fossilize into turnconstructional units (TCUs) for distinct kinds of responsive actions, sometimes short (as is often the case for Estonian küll-utterances), and sometimes complex (as is mostly the case with the Finnish kyl(lä)-utterances). Units are accordingly understood as syntactically, prosodically, and pragmatically potentially complete segments of talk, TCUs, oriented to as such by the participants.

With respect to word order, it is important to note that a great deal of interaction research so far 
has concerned Germanic languages with a primarily fixed word order: English, German, Swedish, and Danish. In this paper we will be looking at two languages that feature a relatively free word order (Heinämäki, 1976; Vilkuna, 1989; Lindström, L., 2005). This type of word order has also been called pragmatic, as different orders are associated with aspects of information structure. Crucially, they also serve distinct interactional purposes. We will show how different social actions are formulated with distinct word orders and special syntactic patterns in Finnish and Estonian, highlighting the contrasts. We thereby illustrate how local patterns of routinization within language communities essentially shape (spoken and interactional) grammar, and locally define the meaning of kyl(lä) and küll. In addition, and more crucially, we will demonstrate that responsiveness, which has been argued to be a concern for turn-beginning (Schegloff, 1996: 69), can also be dealt with at the end of a turn.

Our focus is the adverb/particle kyl(lä)/küll. We suggest that the word has first taken a similar developmental path in the two languages, from the original noun kyllä 'abundance'; German 'Menge, Reichtum', to derivational adverbs like Fi kylliksi, Est küllalt 'enough’ (cf. Hakulinen, L., 1999 [1951]), but that the further developments into especially particle-like usages of $\mathrm{kyl}(l a ̈) / k u ̈ l l ~ d i v e r g e d$, even though both the utterance-initial and utterance-final usages occur in each language. ${ }^{2}$ The fact that the Estonian form küll is monosyllabic is a result of a systematic historical change, apocope, while Finnish preserved the original phonological structure of disyllabic words, also seen in kyllä. In speech kyllä can nevertheless be shortened to kyl, especially in turn beginnings. The letters $\ddot{u}$ vs. $y$ reflect mere orthographic conventions. Regardless of the common etymology, the word is used syntactically and pragmatically differently in Finnish and Estonian, but not always in a straightforward way.

Let us consider the following pair of examples $(1,2)$. Both excerpts come from the beginning of telephone calls and feature a response to the caller's request for another person. These responses include the particle that is in our focus; in Finnish, it is found at the beginning of the utterance and turn, whereas in Estonian, it is in the final position. (Transcription conventions are found at the end of the paper; the target words are not translated in order not to gloss over their complex meaning potential. Glosses are provided merely for the lines in focus.)

(1) Finnish MK 1989 1/A:10

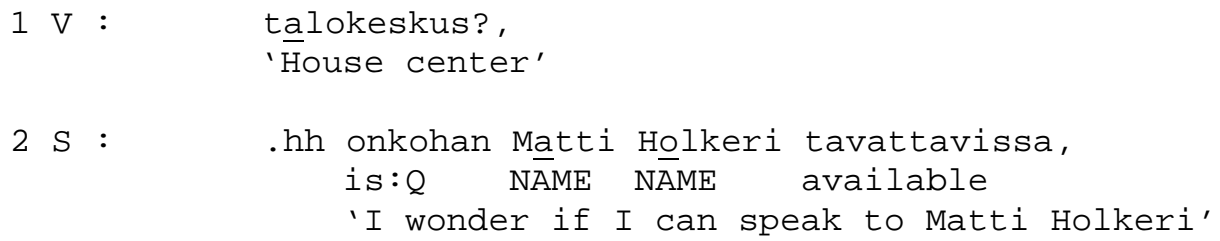

3 $(0.5)$

\footnotetext{
${ }^{2}$ As our focus is on the current usage, we are not going to present the development in detail here. Suffice it to mention an Estonian example from Wiedemann (1875): külla juurest võib võtta 'von der Menge kann man nehmen’. For Finnish, L. Hakulinen (1999) suggested a detachment from constructions like hänellä on kyllä kalaa 'he has a plentitude of fish' > kyllä hänellä on kalaa. In the present-day usage, we can trace the marking of intensity ('to a great degree'), which is close to the original meaning, but also the epistemic meaning of a high degree of certainty and factuality.
} 

$4 \mathrm{~V}: \rightarrow$
kyllä tässä oli
mutta nyt piipahti tuohon
KYLLÄ here be:SG:PST but now drop:SG3:PST there:ILL
'KYLLÄ (he) was here but (he) is just dropping in
5
pankille.
bānk-ALL
at the bank'

(2) Estonian: K3A9

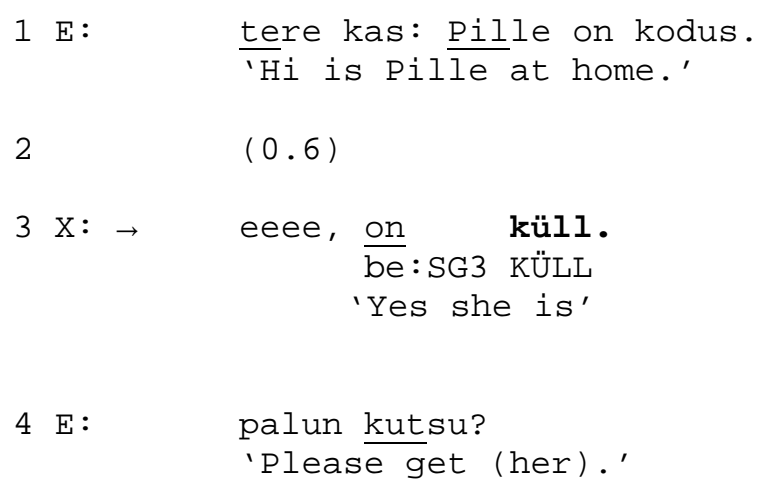

In these two examples, the responsive unit performs basically the same task: the recipient confirms that the person who is being asked for, is either immediately or in principle available. The two responsive turns differ grammatically, with respect to word order and the syntactic complexity of the answer. An affirming response in Finnish is formatted with an initial kyl(lä), which typically projects a complex turn that ends up problematizing the grantability of the request, while Estonian features a final küll in a straightforward affirmation. This reflects interesting differences in function (even with respect to whether the request is granted or not), which is going to be the subject of this paper.

The above mentioned syntactic-pragmatic differences are not easy to explain with any regular word order differences. In fact, comparing languages that both make use of pragmatic word order in greater or lesser extent is a daunting task in itself. Earlier comparative studies on Finnish and Estonian have dealt with abstract patterns (Huumo, 2002) or looked for overall tendencies, such as Estonian featuring more VS than Finnish, which instead favors the SV pattern (Tael, 1988; Huumo, 1994). One major difference is arguably the V2 pattern in Estonian, i.e. that a(n initial) topicalized element, usually an adverb, gives cause to the VS inversion (Tael, 1988: 37-38). These descriptions, based on data from written language and literary translations, do not always correspond to the spoken usage. For example, the Estonian küll-patterns discussed below do not adhere to the V2-rule. With the present paper, we are thus only beginning to address the hitherto unexplored field of comparative Finnish-Estonian spoken language syntax.

In the following we will scrutinize responsive actions accomplished by different kinds of utterances involving $\mathrm{kyl}(l \ddot{a}) / \mathrm{küll}$, as the initial or the final element in a responsive unit. We will show in what ways it underlines speaker certainty or expresses intensity, thereby reinforcing the proposition. On the theoretical side, we will illustrate how dimensions of relative knowledge and actions such as assessing, disagreeing and affirming find a regular grammatical shape in the two 
languages, as reflected in the word order patterns.

After the presentation of the data, the analysis will start by targeting the utterance-initial use, where we can trace some commonality across languages, featuring the semantics of intensity, 'to a great degree', still relatively close to the original meaning of 'abundance'. We will then move on to the utterance-final uses, describing first the Estonian and then the Finnish practices, and demonstrate the semantic-pragmatic differences between the two.

\section{The data}

The Finnish database used in this study derives from the spoken language archive which has been compiled at the Department of Finnish, Finno-Ugric and Scandinavian studies, University of Helsinki (www.helsinki.fi/hum/skl/tutkimus/kesk_arkisto.htm). The data consist of both telephone and video recordings of everyday and institutional conversations, for the most part between speakers from Southern Finland. Kyl(lä) is one of the most frequent words in spoken Finnish, especially in conversations. In the Parole corpus, based on written language, kyllä holds the 116th position, whereas in Arkisyn, the spoken language corpus developed in the department of Finnish and Finno-Ugric Languages, University of Turku, kyllä is No 24 (retrieved 12.11. $2015)$ in the index of word frequencies. There are altogether 228 instances of kyl(lä) in our Finnish collection.

The Estonian data include both telephone calls and face-to-face events, collected by the second author since 1998. The telephone call corpus consists of 324 calls of two types: telemarketing calls from a daily newspaper and everyday calls between family members, friends, and colleagues. Additionally, examples of face-to-face interaction have been used from video recordings of dinner preparations (4 hours), and from the Tartu corpus of Spoken Estonian (http://www.cl.ut.ee/suuline/Korpus.php), which includes excerpts of talk from a wide variety of situations. Küll is a frequent word in Estonian conversation. In the Tartu corpus it held place No 36 in the overall frequency count in everyday spoken interaction, and place No 51 in institutional conversation (Hennoste et al., 2000: 275-283). There are altogether 396 instances of küll in our Estonian collection.

As we are interested in the more productive syntactic patterns, we will for the time being discard formulaic phrases, such as Fi kyllä kai ’yes perhaps' and Est hea küll, approx. 'okay then' (Example 14 presents, however, a relatively formulaic answer). In addition, we will not be looking at the Finnish kyllä as a stand-alone affirming dialogue particle, neither at the initiating actions involving $\mathrm{kyl}(\mathrm{lä}) / \mathrm{küll}$, nor its medial usage. These restrictions allow us to systematically explore the two different eco-systems for $k y l(l a ̈) / k \ddot{l l l}$ and the ways in which they rely on different social-interactional dimensions routinized into grammar.

\section{Utterance-initial use}

In this section, we will focus on utterances where $k y l(l a ̈) / k \ddot{l l l}$ is in the initial position, moving from similar to dissimilar patterns. Section 3.1. presents assessments that have similar routinized patterns in Finnish and Estonian. In 3.2. we take up cases where the usages appear to be next to 
identical: the kyl(lä)/küll-unit counters, or disagrees with, a preceding or succeeding negative assertion by a co-participant. In our database, this is a pattern that occurs rarely in Finnish, but is amply represented in the Estonian data. In 3.3. we discuss the typical Finnish kyl(lä)-initiated affirmation to polar questions. This format in turn has no parallels in Estonian. Finally in 3.4. we take up the Estonian küll-initial units in consolings, which do not have a counterpart in Finnish.

\subsection{Reactive assessments after extended tellings and discussions}

The current section analyses an action that is formatted in a similar way in Finnish and Estonian. Reactive assessments can be used after a telling by the co-participant, or after a longer discussion. The assessment need not be adjacent to its target, and it can also be used as a kind of summarizing comment. In fact, this is a format typically used in both Finnish and Estonian also for observations on non-linguistic states of affairs, e.g., Kyllä on kaunis ilma lit. 'KYLLÄ the weather is beautiful (indeed)'. This usage is characteristically routinized in the format kyl(lä)/küll $(+$ subject $)+$ copula + adjective in both languages.

In an excerpt from a Finnish conversation (3) at a hairdresser's, the client A has told a story of how she succeeded in defending herself when her kiosk was being robbed. When her story has come to a happy end, there is room for amusement at the expense of the robber (lines 4-7). After that the recipient $\mathrm{K}$, the hairdresser, produces a $k y l(l a ̈)$-initial assessment with the whole story in its scope.

(3) Finnish: SG 108

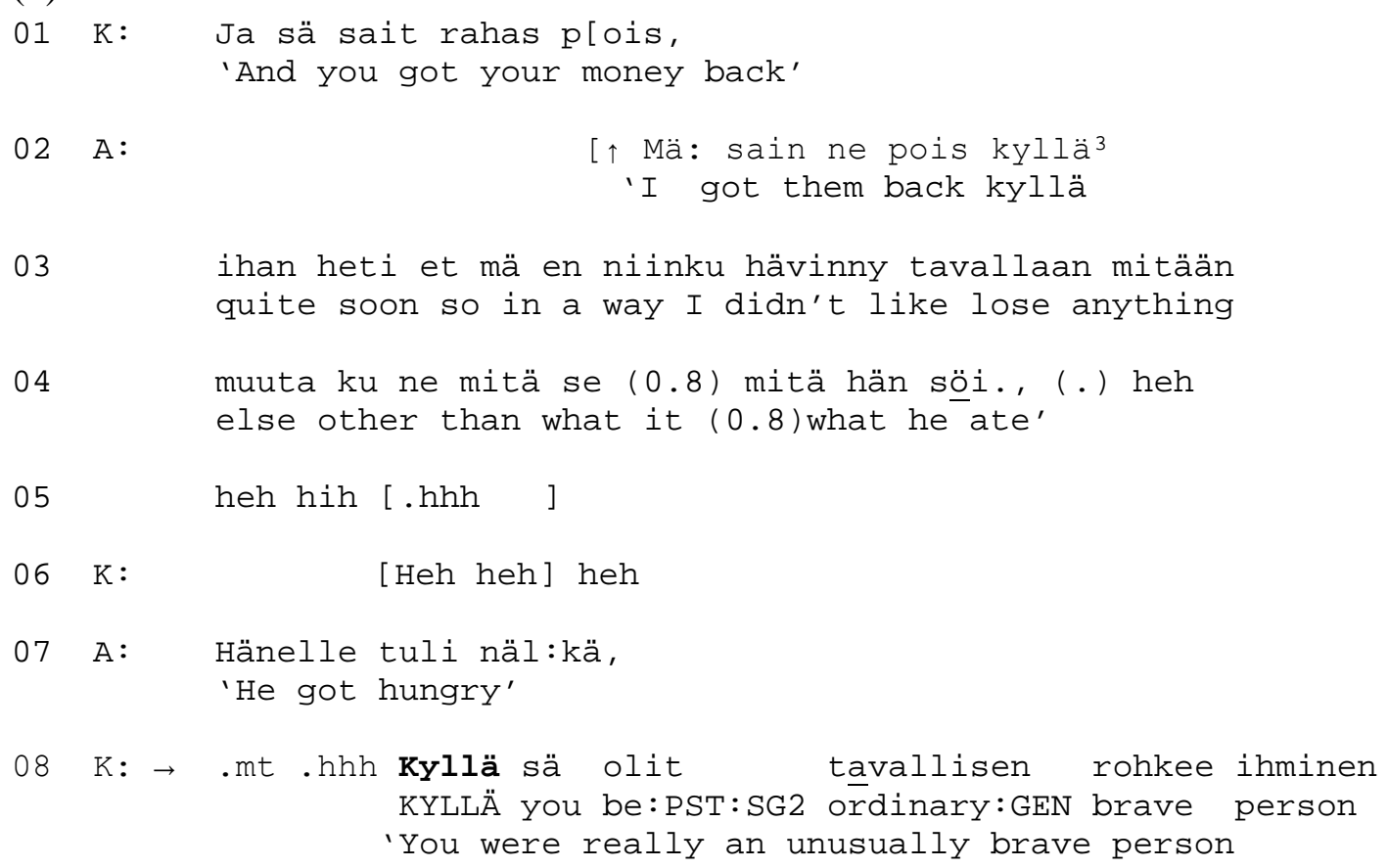

\footnotetext{
${ }^{3}$ In this response turn, kyllä appears, on the face of it, in the middle of a turn, even clause-medially. However, as turns-at-talk are produced step by step, incrementally, what is said at line 2 does in fact form a syntactic unit SVOA + kyllä, i.e., a potential TCU, thereby yielding the particle a unit final status. The speaker thereafter continues her utterance with an incremental adverb ihan heti 'quite soon', and subsequently launches in another TCU, beginning with the paraphrase marker $e t$.
} 
When producing the assessment, $\mathrm{K}$ emphatically praises the co-participant for her bravery. It is the particle kyllä that conveys the intensity in the utterance, in the sense of 'to a great degree', and thereby changes a straightforward statement into one conveying stance. At the same time, $\mathrm{K}$ avoids developing the joking sequence: she does not respond to A's assertion about the thief being hungry. In that sense, the kyl(lä)-initiated assessment constitutes a junction in the conversation, a move on to the evaluation of the protagonist in the story, and thereby perhaps to the conclusion of the story telling activity. Thus, in this sequential position, the initial kyl(lä) does not index that a response is coming; a reaction, yes, but not necessarily a turn that aligns with the prior one.

The corresponding Estonian example (4) is taken from a call between a mother and an adult daughter, who is trying to obtain her skates from her prior home. The mother, her daughter Pille, as well as her sister Kristi have been looking for them in vain. In lines 7-10 Pille says that in case her skates are not found, she will take her sister's. Mother comments on the whole situation as "strange" in a küll-initiated reactive assessment, where the intensifying küll reinforces the claim about strangeness.

(4) Estonian: P5A2

1 Mother: =a uvitav kus nad küll võivad olla.

'But I wonder where they could be.'

2 Pille: vot uvitav, et ma imestan seda et Kristi teadis '( $\left.\mathrm{It}^{\top} \mathrm{s}\right)$ interesting, I'm puzzled because Kristi

3

[kind]lalt et tema omad on seal kapi all, $h$ knew for sure that hers were under the shelves'

4 Pille: [khm khm]

5 Mother: jah, ja olid.

'Yeah, and they were.'

6 Pille: ja olid.

'And they were.'

7 Mother: a sinu omad [ei ole.]

'But yours aren't.'

8 Pille: [aga ] minu omi ei olnud, (๑.3)

'But mine weren't,

$9 \quad$.hh need mis seal toapõrandal on nüd, need ongi Kristi The ones on the floor are Kristi's.

omad. et noh et kui minu omasid ei leita, so if mine are not found, 
then I shall take hers.'

12 Mother: $\rightarrow$ küll on naljakas. sa ise ei mäleta ka

KÜLL be:3SG strange you self NEG remember either

'This is real strange. You don't remember either

13
et kellelegi oleks andnud.=
that someone:ALL:CLI be:COND give:PPT
whether you gave them to someone'

Mother does not respond to the daughter's proposal in lines 10-11. Instead, she chooses to produce an assessment of the whole situation of lost skates in her home (line 12). Immediately after the küll-initiated assessment 'this is strange' she goes on to ask about the possible reason for the disappearance, suggesting among other things that the daughter herself may be responsible. As in the Finnish case, the küll-initiated assessment does not align with the immediately prior turn. Instead, it reacts to the larger exchange.

The regular syntactic structure of Estonian reactive assessments is küll + (subject) + copula + adjective. The subject is rarely expressed, which is different from Finnish. However, the word

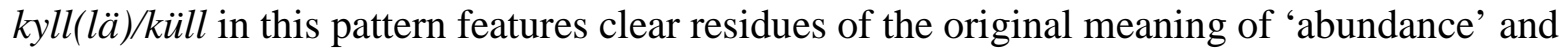

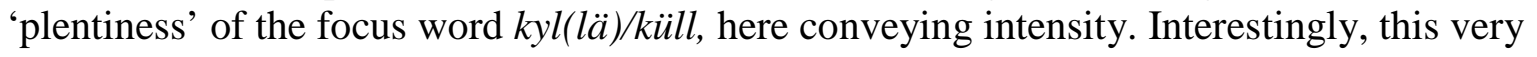
pattern exists in both languages, possibly reflecting a shared earlier historic development.

\subsection{Speaker certainty in disagreements}

In both languages, our focus element has another use: it expresses speaker certainty. Parallel

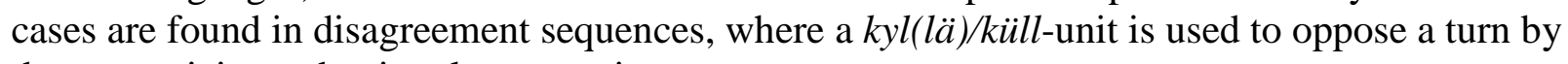
the co-participant that involves negation.

The Estonian turn-initial küll is restricted to responses that disagree with what the prior speaker just said/claimed. In example (5) the speakers are packing a car and talking about whether a mattress fits in a certain space. Eve claims that it will not fit and Siim disagrees with a küll-initial response (line 5). The sequence consists of an assertion and a disagreement. The küll-initiated reaction claims exactly the opposite to what the prior speaker said, even though it is socially affiliative in the sense that Eve probably also wants the mattress to fit in the luggage space. A verb repeat response mahub 'fits' is a minimal structure to turn around the polarity of a negative claim in Estonian, and thus küll clearly emerges as the epistemic reinforcement in this unit.

(5) Estonian: Tartu 631_2

1 Siim: no=näe peaaegu hakkab kõik kotid juba saama ära pakitud. 'See, almost all the bags are getting packed.'

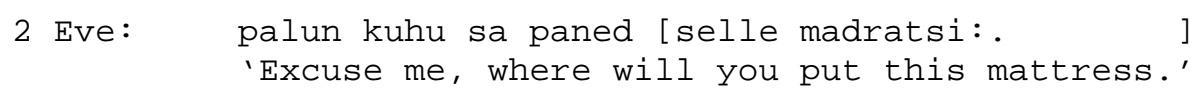

3 Siim: [ma panen selle siia alla]

4 Eve: see ei mahu sinna: .

it NEG fit there:ILL 
'It won't fit there.'

5 Siim: $\rightarrow$ küll ta mahub.

KÜLL it fit:3SG

'Sure it will.'

$6 \quad(\ldots)$

7 Siim: näed ku=mahtus.

'See: it fits.'

As responses to assertions, kyl(lä)-initial turns are relatively rare in our current Finnish data set but quite well established in the system. In these cases kyllä goes against the negative claim of the co-participant's turn: It can be used to project a disagreeing response as well as to occasion a(n almost predictable) disagreeing answer within an ongoing argument. In (6) a couple are arguing whether Jaska, the husband, can go out for a cigarette before the interaction is recorded. At line 1, he asks for a permission to leave (for a smoke); this is gently denied by his wife Jaana ${ }^{4}$. A more explicit disagreement ensues.

(6) Finnish: SG 355

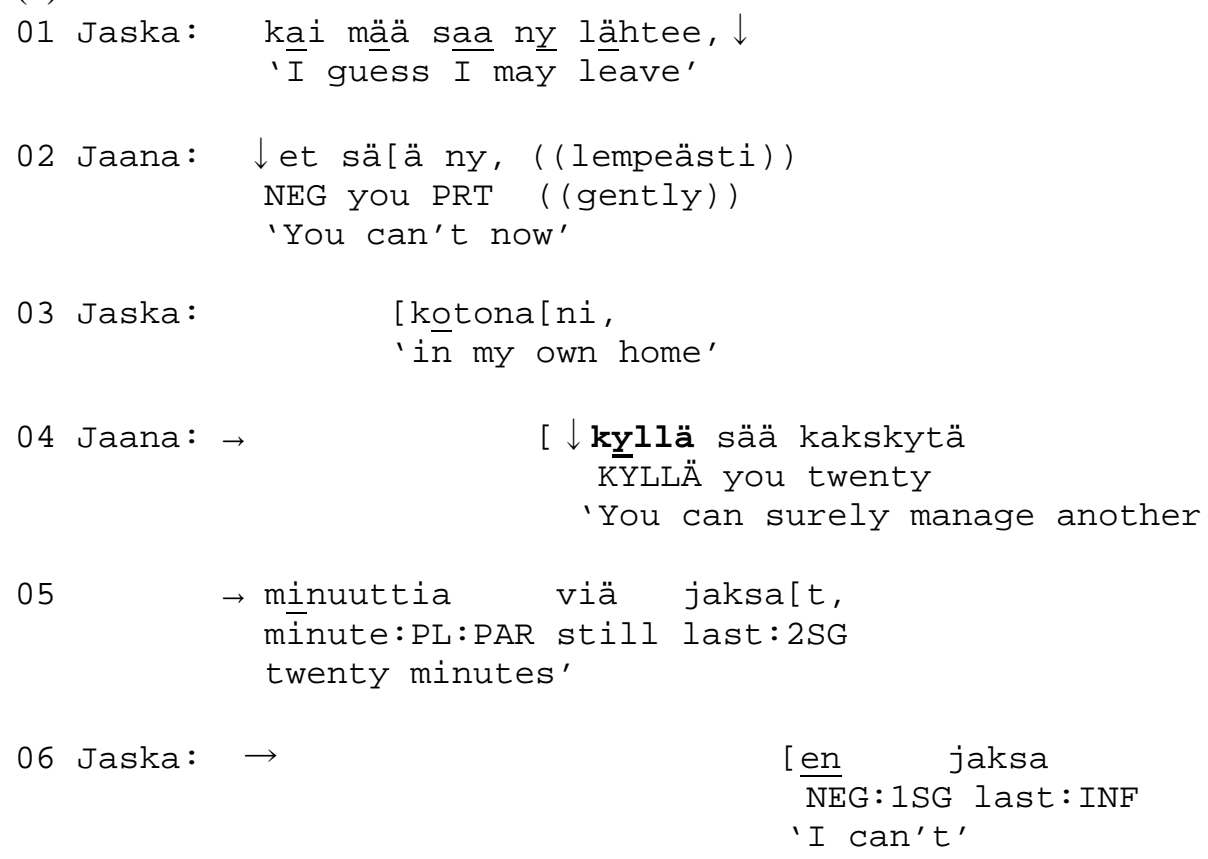

To her own previous turn, Jaana produces a kyllä-initial one (lines 4-5), an epistemically strong claim that Jaska can indeed manage without a cigarette. The disagreeing continues with Jaska’s negative-initial assertion (line 6) countering Jaana's claim.

Finnish and Estonian thus share the disagreeing use of a kyl(lä)/küll-initial utterance. Both focus turns are reinforced by the word $\mathrm{kyl}(\mathrm{lä}) / \mathrm{küll}$ that indexes a high degree of speaker certainty, 'without doubt'. The target word is used utterance-initially, and it is incorporated into the

\footnotetext{
${ }^{4}$ The exchange is somewhat cryptic, as the turns are elliptical, but uniquely understandable in the context.
} 
upcoming prosodic unit. Both kyl(lä) and küll occur in one of the possible syntactic positions for adverbs, they carry major utterance stress, and can therefore be analyzed as epistemic adverbs in this context.

From now on, we are going to specify the pragmatics and sequential aspects of each language separately, as the rest of the patterns turned out to be divergent.

\subsection{Finnish reassuring affirmation/confirmation}

In Finnish, initial kyl(lä) is widely used in answers to polar questions: among the $50 \mathrm{kyl}(l a ̈)$-initial cases in the database, 47 represent answers. One typical use of kyl(lä)-initiated utterances in Finnish is in answers to requests, as was illustrated in (1). Likewise, it is used in responses to interrogatives that ask for information. Examples (7-8) are cases in point. The talk in (7) is about how to fit an old-fashioned mirror on its pedestal, and the speakers are experimenting with fixing it. To Mikko's interrogatively-formatted proposal, which ends with a disjunctive marker vai 'or' two responses are given. First, Jaana admits that she does not know, and partly overlapping with her, Jaska presents an answer beginning with kyl(lä). The answer is thereby marked as positive, complying with the hesitant question functioning as a proposal. We would like to suggest that kyllä also, at the same time, attends to Jaana’s turn and disagrees with her.

(7) Finnish SG 355

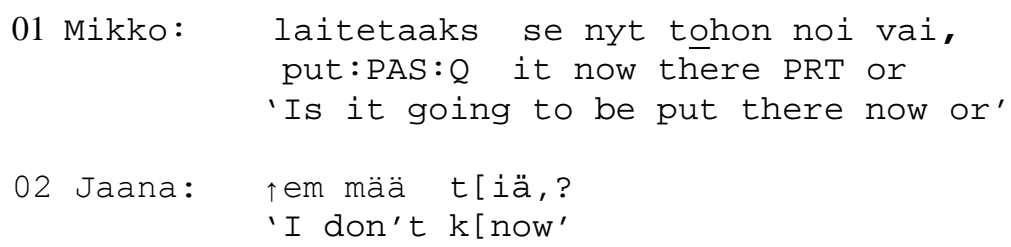

๑3 Jaska: $\rightarrow$

$$
\begin{aligned}
& \text { [kyllä se voitas laittaa, } \\
& \text { KYLLÄ it can:PAS: COND put: INF } \\
& \text { ['KYLLÄ it could be put (there)' }
\end{aligned}
$$

Initial $k y l(l a ̈)$ in this pattern is an index of affirmation but it displays also, from the very beginning of the turn, that the answer will be provided in a manner that takes the terms of the question into account. As Hakulinen (2001) has argued earlier, the kyl(lä)-initial full clause answer is therefore more explicitly forthcoming and aligning than a 'plain' SV-formatted response (se voitas laittaa) would be. An alternative, in fact the default affirmative response type, to a polar question in Finnish would be the repeat of the verb from the question: laitetaan 'is going to be put' (Hakulinen and Sorjonen, 2014).

Crucially, when initiating his/her answer with kyl(lä), the speaker modifies it somewhat instead of simply complying with the terms of the question. ${ }^{5}$ The employment of the initial kyl(lä) in answers to polar interrogatives that perform different functions, enables the recipient to change the course set by the preceding turn while still providing an affirming or strongly aligning response. In addition to this quite frequent practice, $k y l(l a ̈)$ is used to reinforce a positive answer

\footnotetext{
${ }^{5}$ In English conversations, a full clause answer format instead of a particle answer, has been claimed to convey the 'agentivity' of the recipient (cf. Enfield 2011; Raymond and Heritage 2012). In Finnish, at least a kyllä-initial full clause answer does not carry the sense of agency.
} 
to a negatively formulated question. This may be done in the same way as in answers to positive questions. In (8), Sami expresses his doubts about his friend keeping up with the newspaper, employing a negative declarative formatted question, which projects an agreement (cf. VISK, $\S 1203)$. The response provided by Veke counters the challenge of the question with a kyl(lä)initial answer that includes qualifications ('I do try; almost every morning').

(8) Finnish: SG S94-7 Esiviritys

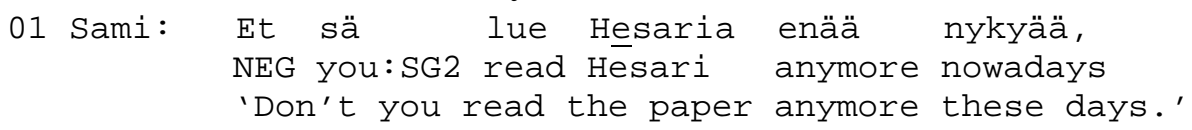

$\odot 2$

03
Veke: $\rightarrow$ Kyl mä: pyrin, (0.7) miltei joka aamu sen lukemaan aina, KYL I try:SG1 almost every morning it:GEN read:INF always 'I do try $(0.7)$ as a rule to read it almost every morning.'

○4 Sami: Ai jaa, et sä oo kattonu nyt näit meijän 'oh I see you haven't been looking at these offers tarjouksii yhtää mitä meil on ollu viime aikoina, of ours at all which we have had recently'

05 Veke: em mä (nyt) tarjouksii ehtiny kattoo, hyvä ku uutiset 'I haven't had time to look at special offers, it takes ehtii lukemaa ja sarjakuvat, enough time to try and read the news and cartoons'

We have now seen how a kyl(lä)-initial answer is used for a reinforced affirmation in Finnish as a response to polar interrogatives used for requests for information (8), simple requests (1), and proposals (7). Kyl(lä)-prefaced responses can either replicate the material from the question and thereby accomplish a (strong) affirmation of it, or reformulate the material to different degrees. With respect to the grammatical format of the response, kyl(lä) at the beginning of the turn gives a clear signal that the first unit of the answer will take a clausal format, and that the answer will be an affirming one. Besides this basic alignment, the answer may involve delays in turn-onset (see line 2 in (8)), as well as modifications later in the utterance, such as the use of modal elements, which qualify the answer as not-quite-aligning in a straightforward manner.

\subsection{Estonian reinforced foretelling}

Initial küll is used in a markedly different manner in Estonian. A unit with the format küll + pronoun + verb constitutes a disaligning answer that undermines some aspect of the prior turn, or even of the entire on-going sequence. In example (9) the mother is talking about the evening meal, telling her adult daughter what is available at home and possibly implicitly advising her to eat it. Instead of receiving the information about different food items, the daughter (Mai) breaks in with a küll-initial response that undermines the relevance of the informing as well as of the advice. The contrastive turn-initial no supports the challenge. In the target line (6) the daughter addresses the implication that she would not find the food on her own.

(9) Estonian: M1A11 


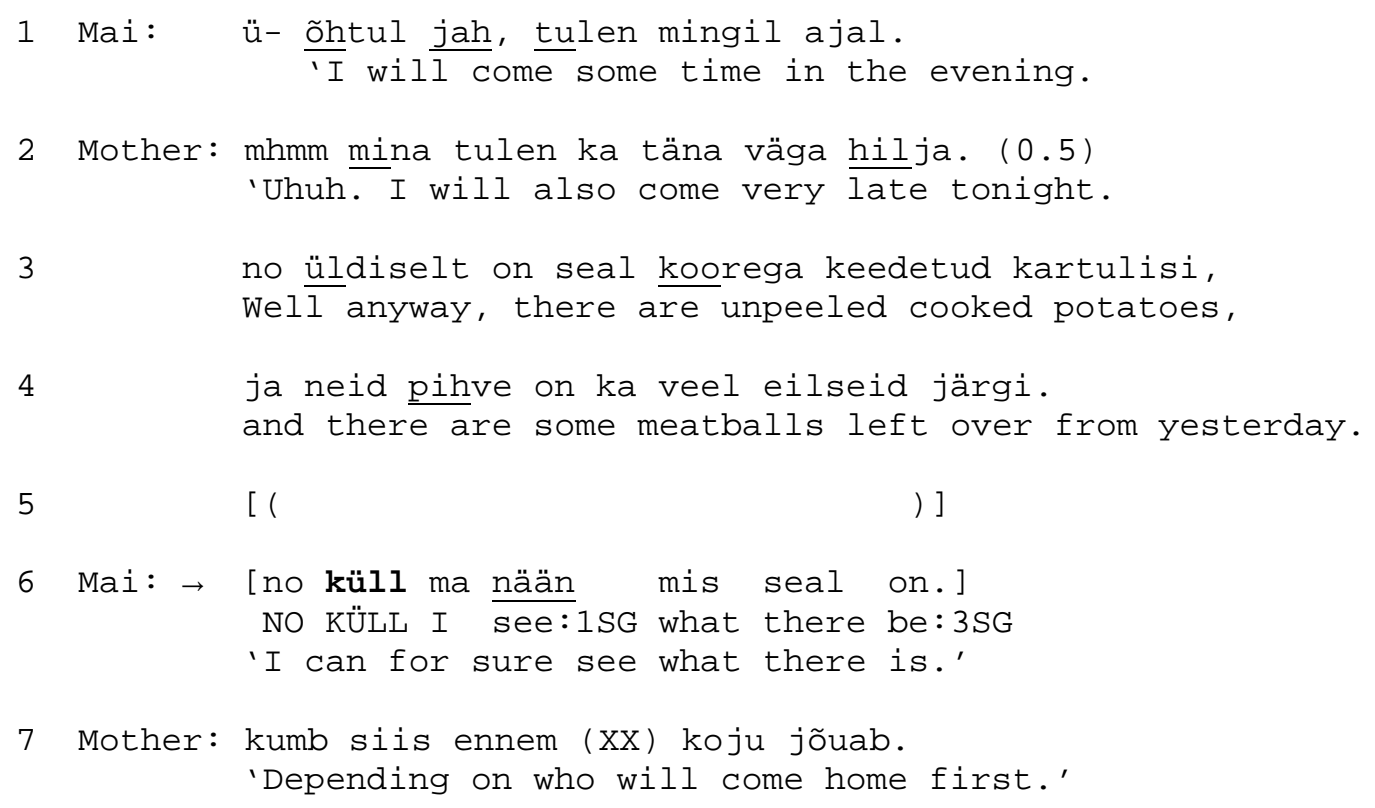

As in the Finnish usage, the Estonian use is indicative of a high degree of certainty. Interestingly, however, the küll-format points to future events (future is not morphologically marked in Estonian). Furthermore, the future is in this pattern always formulated as something positive - an initial küll cannot even be combined with negation in the same utterance. This specific format is dedicated to confronting the prior, but also to underlining speaker certainty about the claim ( 'I can for sure see'), thus epistemically reinforcing it. Excerpt (10) is another illustration of the same pattern, this time with a consoling value. The speaker $\mathrm{T}$ has been complaining about having lost a cassette. He states that he has no more ideas where to look for it (lines 1-3, 7). P disaligns with this complaining activity by uttering a comforting optimistic küll-initial statement in line 8 . It is prefaced by the contrastive particle $a$ 'but', which supports the analysis of these turns as disaligning.

(10) Estonian: P3A8

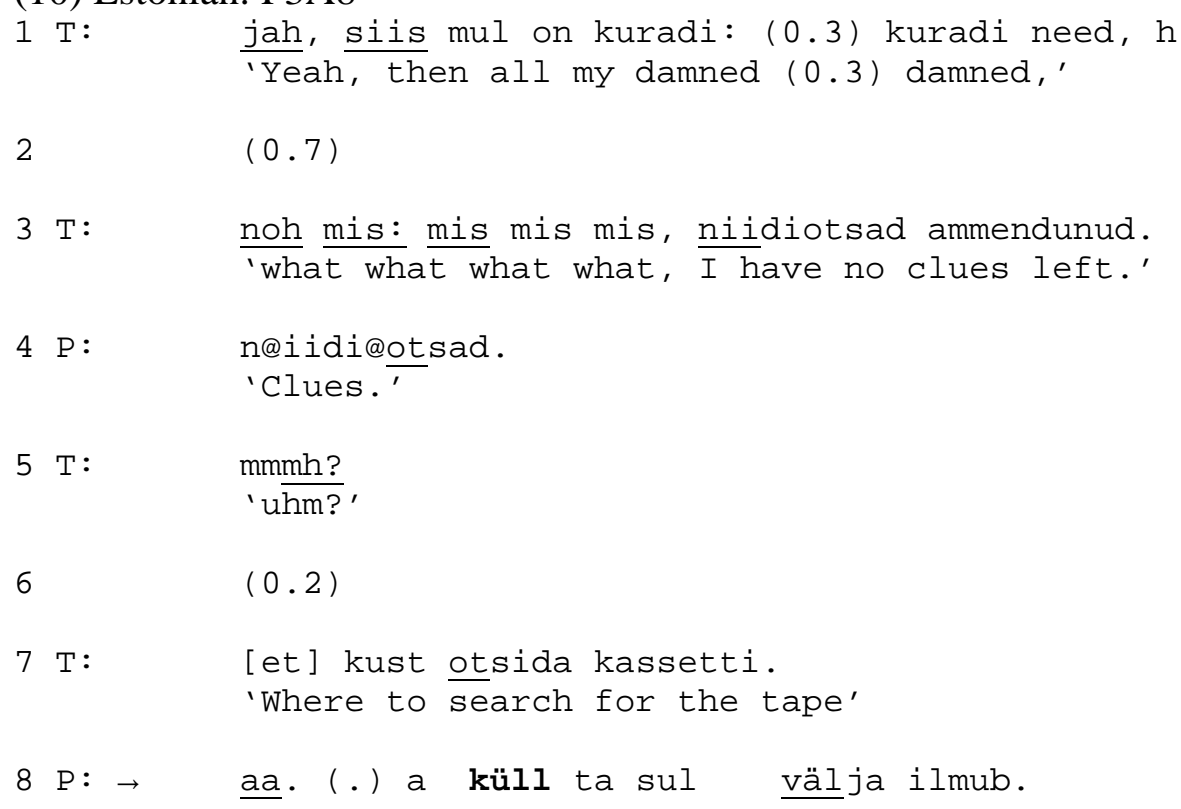


Reactive küll-initiated utterances in Estonian constitute one kind of reinforced action, namely future-oriented positive foretelling. Typically, the state of affairs has been described or implied as a problem in the prior conversation (the mattress not fitting, the daughter not finding food, having lost a tape). The küll-initiated reactive unit provides a positive statement that can undermine the prior speaker in either a confronting (example 9) or a consoling manner (example 10). In fact, there is a slight but systematic pragmatic difference between clauses where the agent is the speaker vs. where s/he is not. While the construction küll $+1^{\text {st }}$ person pronoun underlines the speaker's own conviction of her capacities and displays a challenging stance with respect to what the other just said ('I already know what I will be doing', cf. example 9), küll +2 nd or $3^{\text {rd }}$ person pronoun expresses certainty about something or somebody else and offers a reassuring stance for the recipient ('I am sure it/you'll be fine', cf. example 10). It makes a difference in pragmatic function whose future is formulated as certain.

With respect to the responsive unit structure, küll-initiation in Estonian projects a full clause. The reinforcing turn often recycles lexical material from the prior one, such as repeating the verb mahub 'fit: 3SG' (example 5), seal on 'there is' (example 9), thereby displaying a tight relationship between the turns. The pattern furthermore indexes shared knowledge with 'exophoric' pronouns (such as $t a$ 'it' for the cassette being talked about, the $1^{\text {st }}$ and $2^{\text {nd }}$ person speech act pronouns for the participants). The unit obligatorily exploits the XSV word order, with the subject position, in most cases, filled by a pronoun, which reflects their responsive nature. Full noun phrases are rare: There were only two instances in the current database (out of 41 cases of turn-initial küll). As was pointed out in section 3.3, this is also the case in Finnish. The Estonian küll-initial format counters the recipient's prior pessimism and foretells a positive future with a high degree of certainty, implying that this is also what the recipient would want, e.g. that the mattress fits in, that the daughter will not go hungry, and that the tape will be found.

Supporting the analysis of this pattern as disaligning is the fact that it often takes contrastive particles as prefaces ( $e i$ 'no', $a$ 'but', no 'but, well'), as also shown in examples $(9,10)$. Accordingly, instead of simply calling küll an emphatic word, as is customary in the dictionaries, the close syntactic-sequential analyses reveal its interactional potential of underlining speaker certainty as well as challenging the other's agenda.

\subsection{Summary}

In sections 3.1.-3.2., we established a reactive assessment and a disagreement pattern that is similar across Finnish and Estonian. Sections 3.3.-3.4. illustrated patterns of epistemically reinforced affirming responses to polar questions and complying to requests in Finnish, and the reassuring and consoling expressions that follow neutral information or complaints in Estonian. The kyl(lä)/küll-initial patterns were shown to be grammatically similar but pragmatically different: For the most part, they were used in different sequential positions and they accomplished different actions. It is impossible to use an initial küll in Estonian to provide an affirming answer to a positively formulated question, as shown in 3.3. for Finnish. At the same time, the Finnish initial kyl(lä) can challenge the prior turn when it provides an opposing answer to a negative question, as shown in example (8). Thus, Finnish displays a more flexible sequential and interactional use of kyl(lä) than the Estonian küll, which seems to be more restricted to 
specific formulaic responses, also reflected in the relatively formulaic syntax in the küll + pronoun + verb pattern used for foretellings. With respect to semantics, the words kyl(lä) and küll both currently feature a subjective epistemic sense, which typically develops in the process of grammaticalization (Traugott, 1989; Hopper, 1991; Traugott and Dasher, 2002; Hopper and Traugott, 2003). By offering a reassurance to the other who has just spoken, it simultaneously displays an intersubjective dimension, something that typically develops later in the grammaticalization process (Traugott, 2003). Accordingly, the usage described in this section is likely to feature a semantically later stage of the development of kyl(lä) and küll, where the meanings of 'abundance' and intensity have faded.

\section{Utterance-final use in Estonian: (dis)affirmation}

We will next turn to Estonian responses where küll is used in utterance-final position, as was illustrated in example (2) at the beginning of the paper. For comparison, we will be drawing on the Finnish affirmative pattern illustrated in example (1) and discussed in section 3.3. We are arguing that a) the affirming function is basically the same across the two languages, albeit with slightly different opportunities for modification and expansion; b) in both languages, the speaker can index responsiveness later than at the very beginning of the responsive unit; c) Estonian küll seems to be developing into a clitic while the Finnish typically disyllabic kyllä in the final position is an epistemic adverb.

The utterance-final küll regularly participates in verb repeat responses in Estonian ${ }^{6}$. Verb repeats are used in both Finnish and Estonian as answers to polar interrogatives (cf. above in 3.3.; Keevallik, 2010a; Hakulinen and Sorjonen, 2014). The final küll yields a reassuring function in the Estonian verb repeat answer, as shown in example (11), a telemarketing call from a newspaper office. $\mathrm{M}=$ salesperson, $\mathrm{K}=$ client.

(11) Estonian: S1A1

1 M: e Liivi Linnaleht Tallinnast tülitab [teid].

'Liivi Linnaleht from Tallinn calling.'

$2 \mathrm{~K}$ :

[jaa?]

'Yeah?'

$3 \mathrm{M}: \quad$ hh ee ka:s te nüüd olete: tutvund ka

QUES you:PL now be:2PL acquaint:PPT too

'Have you become acquainted

4 meie Linnalehega.

we: GEN NAME: COM

with our paper now.'

$5 \mathrm{~K}: \rightarrow$ olen küll,

${ }^{6}$ A reviewer pointed out that a turn corresponding to the Estonian target line 5 seems also possible in Finnish. It did not occur in our data base, however - possibly as the data did not include institutional talk. An interesting observation can be made here: whereas küll can be attached to any verb in Estonian, the verb 'be' seems to be the only one in Finnish, thus olen kyllä amounting to a formula. As was previously mentioned, the default answer is a verb repeat. 
be:1SG KÜLL

'I have indeed,'

6 M: ja kuidas rahulolu on.

'And are you satisfied.'

In the target line (5) the client affirms the content expressed in the preceding question, which initiated a pre-sequence. Küll reinforces the answer, featuring remnants of the meaning of intensity, and possibly displaying an orientation to the hedged question (the verb 'become acquainted with' is used instead of something less vague, such as 'read'). The speaker strongly affirms the content but does not explicitly show any understanding of what kind of action sequence was initiated in the prior turn. If anything, it treats the prior question as having been asked in its own right, not as a preliminary to the ensuing one on satisfaction. ${ }^{7}$ As in all the patterns discussed above, $k u ̈ l l$ is uttered from the position of a knowledgeable speaker: It imports a high degree of certainty. It thereby marks that the question has been answered beyond any doubt and constitutes a reinforced affirmation.

Besides affirmatively responding to a positively formulated question as was just shown, the küllreinforced answer is the only grammatical format that can provide a straightforward disaffirming answer to a negatively formulated question:

\section{(12) Estonian: K3B11}

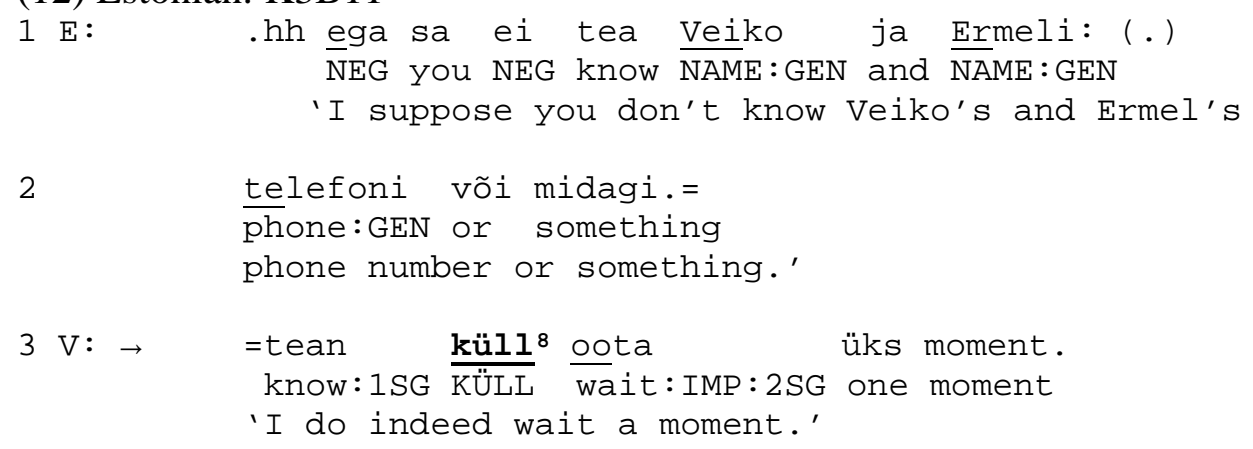

The question about the phone number is here formulated in a conventionally polite negative egaformat (Keevallik, 2009:150-155), and it receives a positive answer, reinforced with the utterance-final küll. In this example, it is also clear that the küll-final unit merely responds to the content of the prior question, while the action import still needs to be dealt with. In the ensuing turn-constructional unit the speaker states that she is going to leave the phone to look for the number, which was implicitly the main aim of the question. While the küll-answer deals with the proposition of the polar question, the second TCU in the turn addresses its action implication. Most importantly, the current polarity-reversing pattern shows that küll functions indeed as a reinforcement of the positive answer: It takes more effort and epistemic certainty to contest a negative proposition in the question. On the other hand, without küll the answer would be ungrammatical. This situation is close to being identical with the Finnish example (8) that also

\footnotetext{
${ }^{7}$ These answers emerge as reassuring even after (hesitant, sceptical) information questions, E.g. Kas üldse saab teha nimodi. - Saab küll. 'May one really do that? - 'You may indeed'; lit. May KÜLL. ${ }^{8}$ There seems to be a prosodic regularity in the verb repeat response pattern: the stress is on the verb in case the question was formulated in positive (ex. 11), and on küll in case it was in negative (ex. 12).
} 
reversed the polarity of the question, but deployed a characteristically different word order.

However, in addition to verb repeats, other elements in a polar question can be affirmed in a küllresponse in Estonian. Here is an example (13) where the adverb aeg-ajalt 'occasionally' is repeated from the question. The excerpt also comes from a telemarketing call.

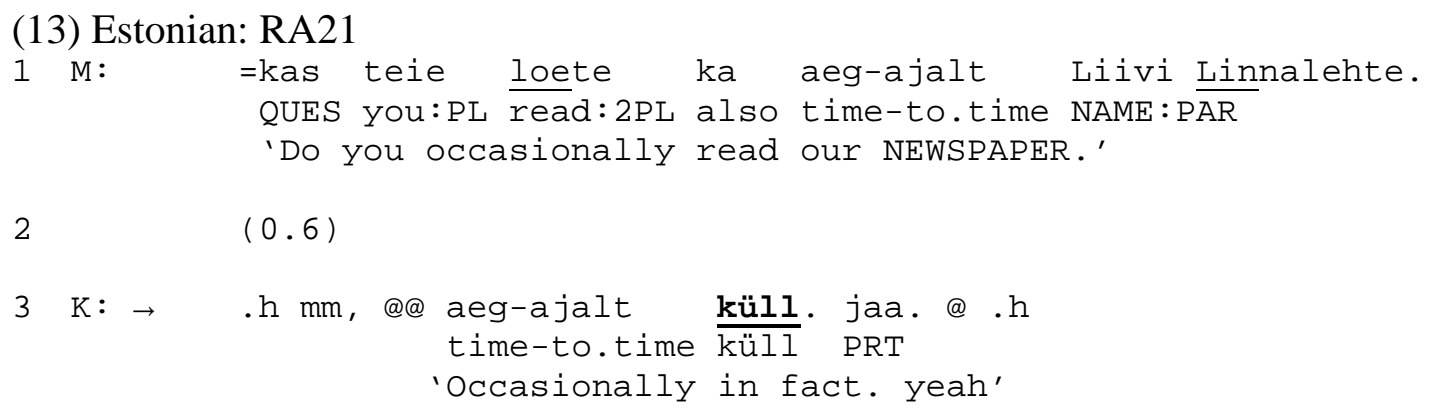

By repeating the adverb, the potential client $\mathrm{K}$ underlines the fact that she only reads the paper occasionally. Accordingly, küll holds a final position in this unit, followed only by the confirmative jaa 'yeah', which constitutes a separate intonation unit and offers an alternative answer to the question. All in all, we are beginning to see that there is a relatively fixed response format $\mathrm{X}+$ küll used for answering polar questions in Estonian.

As it happens, several other modifications regularly occur in the küll-response, such as the lexicalized modal phrases ma arvan 'I think' (Keevallik, 2003), ma usun 'I believe' (Keevallik, 2010b), and ma loodan 'I hope'. This is illustrated in (14). The example comes from the beginning of a phone call, where the caller is apparently trying to get hold of a person at home during work hours. In line (5) he formulates a guess that the person is at work, which receives the modified küll-answer.

(14) Estonian: K1A5

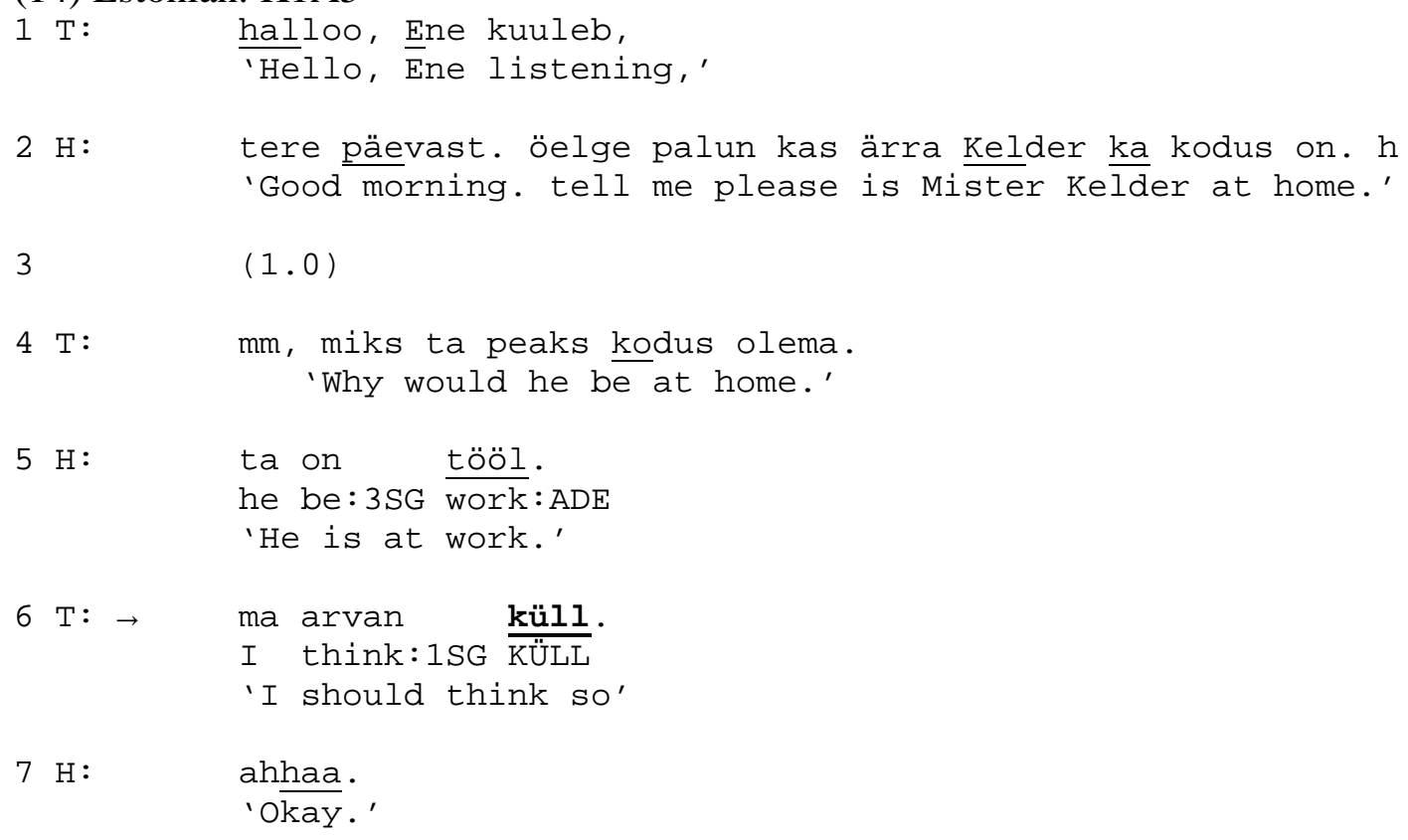


The pattern ma arvan küll, approx. 'I think so' comes close to being a fixed expression, which we chose to leave out in this study (see section 2). To summarize, we can see a clearly formulaic response pattern in Estonian, consisting of $\mathrm{X}+$ küll, where $\mathrm{X}$ is usually a verb or an adverb, rarely an adjective. A küll-final response affirms (a part of) the proposition in the prior turn and does so from an epistemically strong speaker position. On the basis of the systematicity outlined above it is possible to argue that küll is morphologically developing into a clitic in Estonian: It can be added to a variety of syntactically initial elements, and is phonologically attached to them, even though it still carries the main stress. This is in sharp contrast to the Finnish usage of initial kyl(lä) in affirmative responses, which allows for considerable syntactic variation in the ensuing talk. In both languages, the target item conveys epistemic certainty but its syntactic position and grammatical status are different. In Estonian it seems to be emerging as a more dependent element syntactically.

One outcome of this difference is that the Finnish responses regularly provide an occasion for expansion, specification and elaboration after kyl(lä) (as shown in example 1, and in section 3.3.). Instead, in Estonian many küll-responses are formulaic, while same-clause elaboration is still possible before küll. This is illustrated in example (15), where Tiia proposes a meeting and asks whether Piret has time on Sunday, to which Piret responds with a modified clausal answer. The unit-final küll is here combined with $j a h$, which is a reasonably frequent combination.

(15) Estonian: K1A9

1 Tiia: aga::, saame siis pühapäeval kokku, sis vaatame, hh

2 .h kas sul on pühapäeval aega.

QUES you:ADE be:3SG Sunday:ADE time:PRT

will you have time on Sunday.'

3

4 Piret: $\rightarrow$ mul peaks olema küll jah, I:ADE must:COND be:SUP KÜLL PRT

'I should indeed have yeah,'

In contrast to Finnish, elaborations and modifications are accomplished before the affirmatory küll. This means that Finnish speakers will know from the beginning of the unit that the response will be basically affirming, while Estonian speakers are bound to wait until later, when the affirmatory verb repeat or küll is uttered. Affirmative patterns in Finnish and Estonian thus seem to display opposite word orders in responsive units, featuring initial kyl(lä) in Finnish and final küll in Estonian. (cf. Section 5, however.) Whether this leads to different recipient behavior and real-time interactional consequences, remains to be studied. What we would like to underline in our present analysis, is the fact that indexing affirmation can also be accomplished later in a turn. Thus, explicit back-linking to a prior turn with a response particle is not handled only at the beginning of turns, as suggested in e.g. Schegloff (1996: 95).

5. Utterance-final use in Finnish: epistemicity 
While Estonian final küll was shown to be a regular element in relatively formulaic answers, the Finnish final kyllä is more flexible in terms of syntax as well as with respect to pragmatics. In the current section, we will be illustrating a Finnish utterance-final usage that is altogether nonexistent in Estonian.

In Finnish, the responsive kyllä-final utterances and turns are used in both negative and positive answers to polar interrogatives. In example (16), from the beginning of a call, a positive answer is projected or presupposed by the question. Siiri's question in line 5 offers a possible explanation to the weak connection between the speakers: Missu is using the old landline phone. However, the answer she receives is a negative one, ending with the adverb kyllä.

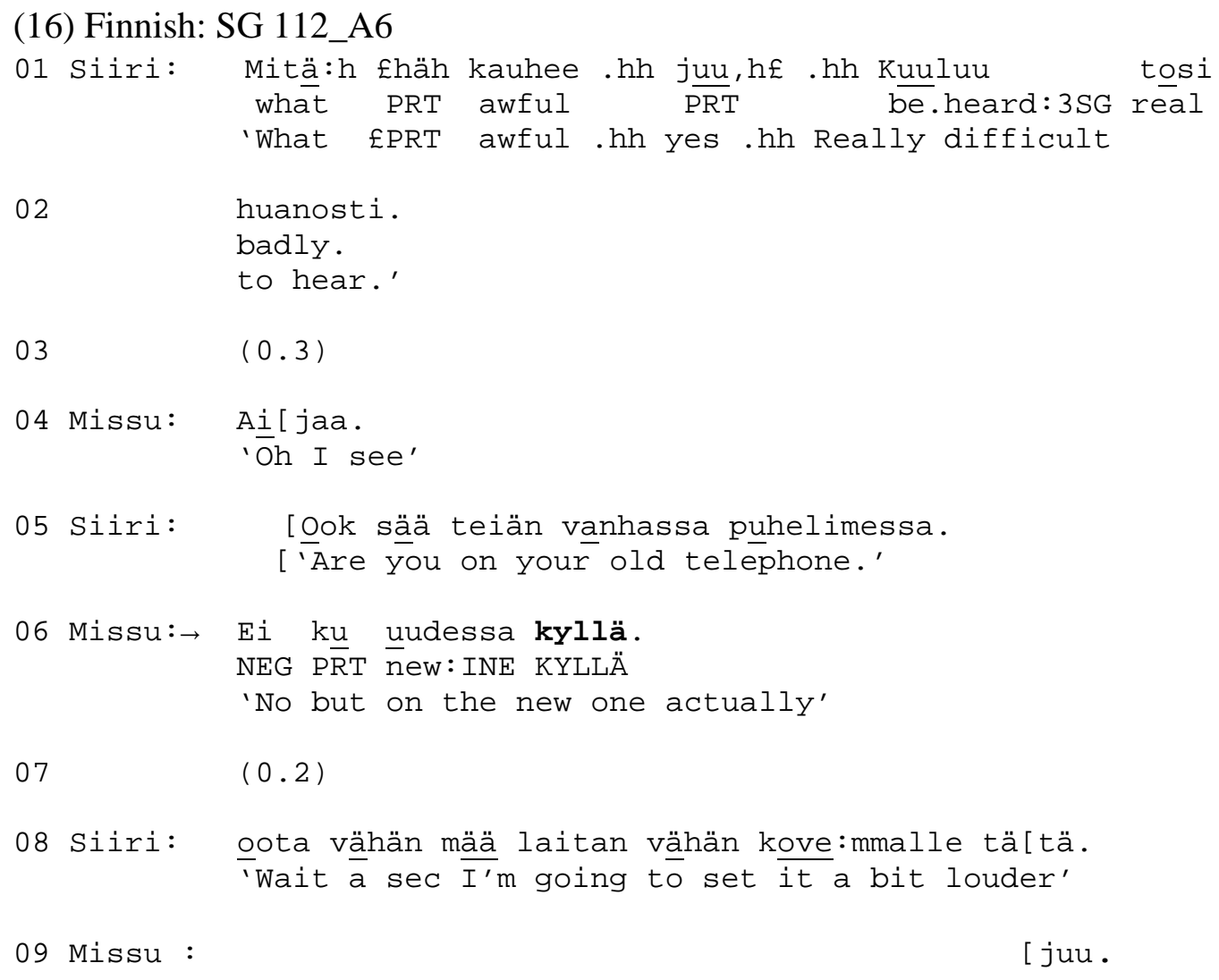

A negative answer without the final kyllä would be a simple, straightforward disconfirmation of the primary alternative ('on the old phone') conveyed by the question. Here, instead, the final kyllä is used to target the presupposition in the question that the bad sound is due to her using the old phone and reassure the recipient that this is not true. Kyllä thus adds the meaning of 'in fact', or 'actually' ('contrary to what you were surmising') to the answer.

In example (17), two middle aged sisters are chatting in Tuula's kitchen. A previous topic has been closed, and the speakers search for a next one. Jaana accomplishes this with a 'by-the-way' question, bringing up something that meets the eye in the context (cf. Bergmann, 1990). She enquires about the acquisition of the kitchen curtains (lines 1-2). There is an extensive exchange between the question and the kyllä-final answer (lines 20-21). During the exchange, Tuula first 
confronts Jaana at line 8: it was Jaana herself who had sewn the curtains years ago. Despite being formatted as an affirmative declarative, Tuula's answer in lines (20-21) implies a negative response: the curtains were not sewn for the kitchen. This way of conveying a negative response is reminiscent of non-corrections described by Jefferson (1987).

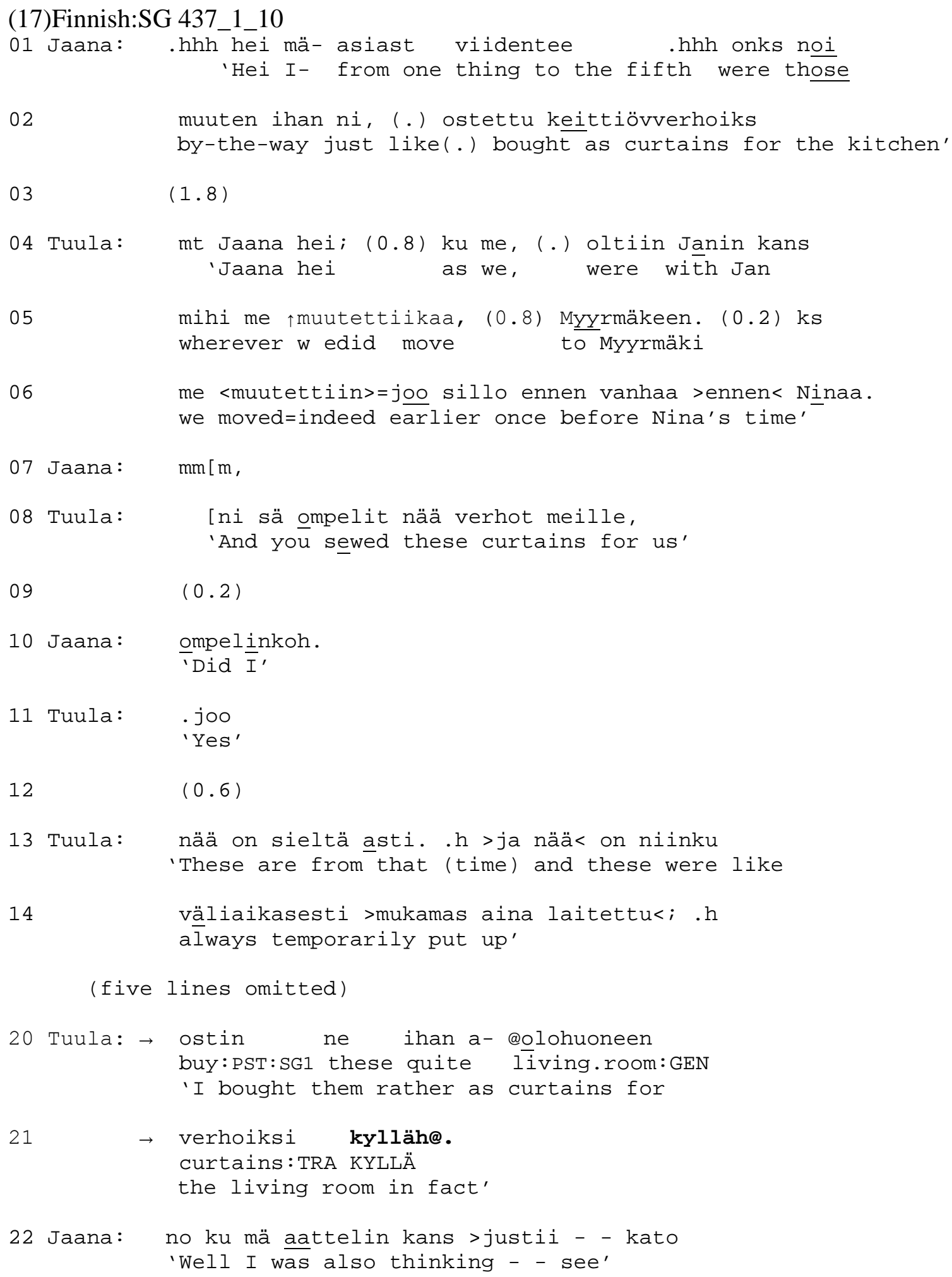


Instead of a negative answer that would refute Jaana's memory about the curtains (lines 1-2), Tuula at first launches a story about the situation of curtains in her household, and then presents a positive declarative utterance (lines 20-21) that describes an alternative version and ends it with kyllä. Here, the turn-final epistemic adverb conveys the implication that Jaana's question can be viewed as not completely wrong.

The clear difference between the cases in $(16,17)$ and the modified $k y l(l a ̈)$-initial affirming answers discussed in 3.1 is that the kyllä-final ones convey a different, even an opposite standpoint but as if camouflaged in a positive statement of a fact owned by the speaker. In addition, a kyl(lä)-final response does not have to be contiguous, as shown in (17). In sum, while the kyl(lä)-initial turn immediately indexes that what follows is an aligning affirmation, a kylläfinal one as it were leaves it to the co-participant to infer the pragmatic import of the response. Crucially, whereas 'intensity' is still profiled in the Estonian küll-final answers, the Finnish ones clearly convey the sense of speaker 'conviction', i.e. a high degree of certainty.

\section{Concluding discussion}

In this paper, we accounted for the responsive and reactive units encompassing $\mathrm{kyl}(\mathrm{lä}) / \mathrm{küll}$ in Finnish and Estonian, and showed how a responsive element can occur in the initial as well as in the final position in a unit (cf. Schegloff, 1996). We argued that in both languages, kyl(lä)/küll basically expresses intensity and speaker certainty, featuring a distinctly epistemic meaning, and functioning as a reinforcement of the proposition.

Two of the utterance-initial usages were similar: where kyl(lä)/küll occurs in disagreeing units, and where it is a part of a reactive assessment after a longer telling or discussion. The assessment pattern features syntactic structures that are routinized in a similar way across the two languages

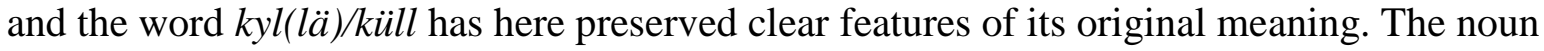
'abundance' and the intensity adverb ‘to a great degree' are semantically close. We also found two major differences. First, in Finnish, kyl(lä)-initial utterances are predominantly affirming answers to polar questions, while in Estonian küll-initial utterances are only used as futureoriented positive foretellings. In these, the target word expresses epistemic certainty. Second,

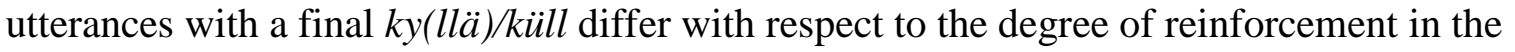
response. In Estonian, küll-final turns may convey a strong disaffirmation to a negatively formatted question, featuring intensity and certainty, whereas in Finnish, they yield an indirect way of going against the presupposition of the preceding question, featuring the highest degree of certainty, conviction. While the Finnish kyl(lä) is mostly used in turns where alignment is profiled, the Estonian küll is regularly also deployed for disaligning actions: the kyl(lä)/küll-initial utterance is an affirming response in Finnish and a disaligning foretelling in Estonian.

Apparently, similar syntactic patterns can become routinized in divergent functions when regularly deployed in different sequential positions. In short, by comparing the initial and the final utterance positions, and looking closely at the action sequences, we were able to demonstrate systematic connections between word order, lexical meaning, and social action across two related languages.

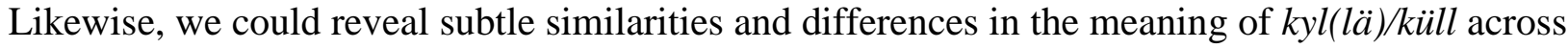


the two languages. The etymologically shared original noun $k y l(l a ̈) / k u ̈ l l$, documented with the meaning 'abundance', 'plentiness', has currently come to indicate intensity and a high degree of certainty as an adverb, while the Finnish final kyllä conveys a further sense of 'conviction'. Kyl(lä)-use in Finnish is syntactically more flexible, as it can be used as a preface or an increment (Schegloff, 1996: 91). In contrast, the Estonian küll figures in succinct, almost formulaic clauses and phrases, and may be losing its status as an independent word in the unit-final patterns. More broadly, Finnish kyl(lä) is mostly cooperative in initial position and slightly more disaligning later in the turn (Hakulinen 2001), while Estonian küll is the other way around. The Finnish final kyllä emerges as an epistemic adverb that conveys its speaker's knowledgeable status, while the Estonian final küll may also confirm that the prior speaker was right, and thereby places the current speaker equal with respect to mutual knowledge. In all the above cases, the target word displays usages beyond its original meaning that reflect the particular nuances of the sequential social action that it is part of. Action and word-meaning are thus in a mutually reflexive relationship.

This study illustrates the importance of studying lexis and grammar in a positionally sensitive manner: We were able to show how language structure can be systematically dependent on its immediate interactional context. We focused on one conversational position at a time, and discovered differences between sequences initiated by polar questions, assertions, informings, complaints and requests, across as well as within languages. Even though the current analysis

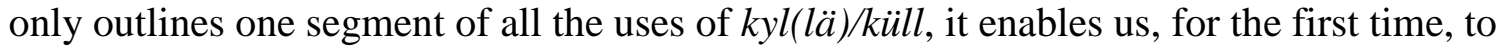
establish clear contrasts between superficially similar syntactic patterns and words that appear to carry similar pragmatic meanings in Finnish and Estonian. These findings complement traditional studies on lexical relations in genetically related languages, showing how conversational function may feature in them.

\section{Transcription conventions}

\begin{tabular}{ll} 
underlining & - emphasis \\
\hline- & - truncation \\
{$[$ ] } & - overlaps; timing of embodied action \\
$=$ & - latching of turns \\
$(0.5)$ & - pause length in tenths of a second \\
$()$. & - micropause \\
$:$ & - lengthening of a sound \\
$<@>$ & - laughing quality \\
.h & - breathing in \\
$(\mathrm{m}) \mathrm{h}$ & - breathing out \\
o & - low volume \\
boldface & - the focused particle and repeated materials in the excerpt \\
? & - pitch fall at the end of an intonation/prosodic unit \\
? & - pitch rise at the end of an intonation/prosodic unit \\
- & - level pitch at the end of an intonation/prosodic unit \\
& - unfinished (intonation) unit
\end{tabular}




$\begin{array}{ll}\uparrow & - \text { sharp rise in tone } \\ \text { (not in the original) } & - \text { the part is not expressed in the original } \\ \text { (X) } & - \text { unhearable syllable }\end{array}$

Abbreviations

$\begin{array}{ll}\text { 1, 2, 3 } & \text { - person } \\ \text { ADE } & - \text { adessive } \\ \text { CLI } & \text { - clitic } \\ \text { COM } & \text { - comitative } \\ \text { COND } & - \text { conditional } \\ \text { DET } & - \text { determiner } \\ \text { GEN } & - \text { genitive } \\ \text { ILL } & - \text { illative } \\ \text { IMP } & - \text { imperative } \\ \text { INF } & - \text { infinitive } \\ \text { INS } & - \text { inessive } \\ \text { NAME } & - \text { name } \\ \text { NEG } & - \text { negation } \\ \text { PAR } & - \text { partitive } \\ \text { PAS } & - \text { passive } \\ \text { PL } & - \text { plural } \\ \text { PPT } & - \text { past participle } \\ \text { PRT } & - \text { particle } \\ \text { PST } & - \text { past } \\ \text { Q } & - \text { question clitic } \\ \text { QUES } & - \text { question particle } \\ \text { SG } & - \text { singular } \\ \text { SUP } & - \text { supinum } \\ \text { TRA } & - \text { translative } \\ \text { Other capital letters } & - \text { an untranslatable particle } \\ & \end{array}$

\section{References}

1. Auer, Peter 2009. On-line syntax: Thoughts on the temporality of spoken language. Language Sciences 31: 1-13.

2. Auer, Peter and Maschler, Yael 2013. Discourse or grammar? VS patterns in spoken Hebrew and spoken German narratives. Language Sciences 37: 147-181.

3. Bergmann, Jørg 1990. On the local sensitivity. In: I. Markova \& K. Foppa (eds.), The dynamics of Dialogue. New York: Harvester Wheatsheaf. Pp. 201-226.

4. Clayman, Steven \& Heritage, John C. 2002. The News Interview: Journalists and public figures on the air. Cambridge: Cambridge University Press.

5. Enfield, Nick J. 2011. Source of asymmetry in human interaction: enchrony, status, knowledge and agency. In: T. Stivers et al. (eds.), The Morality of Knowledge in Conversation. 
Cambridge: Cambridge University Press. Pp. 285-312.

6. Fox, Barbara and Thompson, Sandra 2010. Responses to wh-questions in English conversation. Research on Language and Social Interaction 43(2): 133-156.

7. Grünthal, Riho 2000. Typological characteristics of the Finnic languages: a reappraisal. In: Laakso, J. (ed.) Facing Finnic. Some challenges to historical and contact linguistics. Castrenianumin toimitteita 59, Finno-Ugrian Society, Department of Finno-Ugrian Studies of the University of Helsinki. Pp. 31-63.

8. Hakulinen, Auli 2001. On some uses of the discourse particle kyl(lä) in Finnish conversations. In: Selting, M. \& E. Couper-Kuhlen (eds.), Studies in Interactional Linguistics. Amsterdam: John Benjamins. Pp. 179-198.

9. Hakulinen, Auli \& Sorjonen, Marja-Leena 2009. Designing utterances for action: Verb repeat responses to assessments in Finnish. In: M. Haakana et al. (eds.) Talk in interaction. Comparative dimensions. Helsinki, Finnish Literature Society. Pp. 124-151.

10. Hakulinen, Auli \& Sorjonen, Marja-Leena 2011. Ways of agreeing with negative stance taking. In Tanya Stivers, Lorenza Mondada and Jakob Steensig, eds., The Morality of Knowledge in Conversation. Cambridge, Cambridge University Press. Pp. 235256.

11. Hakulinen, Auli \& Sorjonen, Marja-Leena 2014. Verb repeats and beyond. ICCA-14, UCLA, Los Angeles, June 25-29, 2014.

12. Hakulinen, Lauri 1999 [1951]. Luennot suomen kielen partikkeleista. \{Lectures on Finnish particles]. Toimittaneet Yrjö Lauranto ja Tapani Lehtinen. University of Helsinki, Department of Finnish.

13. Heinämäki, Orvokki 1976. Problems of basic word order. In: N.E. Enkvist \& V. Kohonen (eds.) Reports on Text Linguistics: Approaches to Word Order. Meddelanden från Stiftelsens för Åbo Akademi Forskningsinstitut 8: 95-106. Turku: Åbo Akademi.

14. Hennoste, Tiit, Lindström, Liina, Rääbis, Andriela, Toomet, Piret \& Vellerind, Riina 2000. Eesti suulise kõne korpus ja mõne allkeele võrdlemise katse [The spoken language corpus of Estonian and an attempt to compare some varieties]. In: Tiit Hennoste (ed.), Arvutuslingvistikalt inimestele [From computer linguistics to people]: TÜÜÕT 1. Tartu: Tartu University Publishers. Pp. 254-284.

15. Heritage, John \& Raymond, Geoffrey 2012. Navigating epistemic landscapes: Acquiescence, agency and resistance in responses to polar questions. In: J-P de Ruiter (ed.) Questions. Formal, functional and interactional perspectives. Cambridge: Cambridge University Press. Pp. 179-192.

16. Hopper, Paul 1991. On some principles of grammaticization. In: E. Traugott \& B. Heine (eds.) Approaches to Grammaticalization. Vol 1. Theoretical and Methodological Issues. Amsterdam/Philadelphia: John Benjamins. Pp. 17-35.

17. Hopper, Paul \& Traugott, Elisabeth 2003. Grammaticalization. Cambridge: Cambridge University Press.

18. Huumo, Tuomas 1994. Näkökulmia suomen ja viron sanajärjestyseroihin. In: Sulkala, Helena \& Laanekask, Heli (eds.) Lähivertailuja 8, Suomalais-virolainen kontrastiivinen seminaari Hailuodossa 7.-9.5.1994: Research reports from the Department of Finnish and Saami, University of Oulu 40:21-39. Oulu.

19. Huumo, Tuomas 2002. Syntax or discourse pragmatics: A contrastive analysis on Finnish and Estonian word order. In: L. I. Rábade \& S. M. Doval Suárez (eds.) Studies in Contrastive Linguistics. Proceedings of the 2nd International Contrastive Linguistics Conference, Santiago de Compostela, October 2001. Universidade de 
Santiago de Compostela. Santiago. Pp. 495-502.

20. Iwasaki, Shimako 2011. The multimodal mechanics of collaborative unit construction in Japanese conversation. In: J. Streeck, C. Goodwin \& C. LeBaron (eds.) Embodied Interaction: Language and Body in the Material World. Cambridge: Cambridge University Press. Pp. 106-120.

21. Jefferson, Gail 1987. On exposed and embedded correction in conversation. In: G. Button \& J.R.E. Lee (eds.), Talk and Social Organization. Clevedon, UK: Multilingual Matters. Pp. 86-100.

22. Kauppinen, Anneli 2006. Polyseeminen “vaikka” ja neuvottelun retoriikka. [Polysemous vaikka and the rhetorics of negotiation] Virittäjä 110(2): 162-189.

23. Keevallik, Leelo 2003. From Interaction to Grammar: Estonian Finite Verb Forms in Conversation. Acta Universitatis Upsaliensis. Studia Uralica Upsaliensia 34. Uppsala.

24. Keevallik, Leelo 2009. The grammar-interaction interface of negative questions in Estonian. SKY Journal of Linguistics 22: 139-173.

25. Keevallik, Leelo 2010a. Minimal answers to yes/no questions in the service of sequence organization. Discourse Studies 12(3): 1-27.

26. Keevallik, Leelo 2010b. Clauses emerging as epistemic adverbs in Estonian conversation. Linguistica Uralica 46(2): 81-100.

27. Keevallik, Leelo 2010c. Hinnangu grammatikast. [On the grammar of assessments.] In: I. Tragel (ed.), Keele rajad. Pühendusteos professor Helle Metslangi 60. sünnipäevaks. Eesti ja soome-ugri keeleteaduse ajakiri 2: 147-161.

28. Lindström, Jan 2014. On the place of turn and sequence in grammar: Verb-first clausal constructions in Swedish talk-in-interaction. Pragmatics. 24(3): 507-532

29. Lindström, Liina 2005. Finiitverbi asend lauses. Sõnajärg ja seda mõjutavad tegurid suulises eesti keeles. (PhD dissertation) [The place of a finite verb in a sentence. Word order and its factors in Estonian.] Tartu: Tartu Ülikooli Kirjastus

30. Maschler, Yael 2015. Word order in time: Emergent Hebrew (Ns)V/VNs syntax. In: A. Deppermann \& S. Günthner (eds.) Temporality in Interaction, Studies in Language and Social Interaction Series, Amsterdam: John Benjamins. Pp. 201-236.

31. Raymond, Geoffrey 2003. Grammar and social organization: Yes/No interrogatives and the structure of responding. American Sociological Review 68, 939-967.

32. Schegloff, Emanuel A. 1996. Turn organization: one intersection of grammar and interaction. In: E. Ochs, E.A. Schegloff \& S.A. Thompson (eds.) Interaction and grammar. Cambridge: Cambridge University Press. Pp. 52-133.

33. Sorjonen, Marja-Leena \& Hakulinen, Auli 2009. Alternative responses to assessments. In: J. Sidnell (ed.) Conversation analysis. Comparative Perspectives. Cambridge: Cambridge University Press. Pp. 281-303.

34. Stivers, Tanya 2005. Modified Repeats: One method for asserting primary rights from second position. Research on Language and social Interaction 38(2): 131-58.

35. Stivers, Tanja \& Hayashi, Makoto 2010. Transformative answers: One way to resist a question's constraints. Language in Society 39: 1-25.

36. Stivers, Tanja, Steensig, Jakob \& Mondada, Lorenza 2011. Knowledge, morality and affiliation in social interaction. In: T. Stivers et al. (eds.) The Morality of Knowledge in Conversation. Cambridge: Cambridge University Press. Pp. 3-24.

37. Tael, Kaja 1988. Sõnajärjemallid eesti keeles (võrrelduna soome keelega). [Word order patterns in Estonian (compared to Finnish).] Preprint KKI-56. Tallinn. 
38. Tanaka, Hiroko 2000. Turn projection in Japanese Talk-in-Interaction. Research on Language and Social Interaction 33(1): 1-38.

39. Thompson, Sandra A., Fox, Barbara A. \& Couper-Kuhlen, Elizabeth 2015. Grammar in Everyday Talk: Building Responsive Actions. Cambridge: Cambridge University Press.

40. Traugott, Elizabeth C. 1989. On the rise of epistemic meaning in English: an example of subjectification in semantic change. Language 65: 31-55.

41. Traugott, Elizabeth C. 2003. From subjectification to intersubjectification. In: Raymond Hickey (ed.) Motives for Language Change. Cambridge: Cambridge University Press. Pp. 124-139.

42. Traugott, Elizabeth C. \& Dasher, Richard B. 2002. Regularity in Semantic Change. Cambridge: Cambridge University Press.

43. Vilkuna, Maria 1989. Free word order in Finnish. Its syntax and discourse functions. SKST 500. Helsinki: Finnish Literature Society.

44. VISK = Hakulinen, A., M. Vilkuna, R. Korhonen, V. Koivisto, T. Heinonen \& I. Alho 2008. Iso suomen kielioppi (A Comprehensive Grammar of Finnish). http://www.kotus.fi/julkaisut/kielioppi-_ja_kielenhuoltokirjat/iso_suomen_kielioppi

45. Wiedemann, F. J. 1875. Grammatik der Estnischen Sprache, zunächst wie sie in Mittelehstland gesprochen wird, mit Berücksichtigung der anderen Dialekte. St. Petersburg.

46. Wide, Camilla 2014. The functions of subjectless declarative main clauses in spoken Swedish. Journal of Pragmatics 63: 35-47. 